\title{
AN ECONOMETRIC STUDY OF THE PRESENT AND FUTURE EFFECT OF INFLATION ON ECONOMIC GROWTH IN EGYPT
}

\author{
Rihan ${ }^{1}$, M.K. and Sally A. Bawady ${ }^{2}$ \\ 1- Agric. Economics Dept., Fac. of Agric., Ain Shams Univ., Cairo, Egypt \\ 2- Economic Studies Dept., Socio, Economic Studies Division, Desert Research Center, Cairo, \\ Egypt
}

Keywords: Inflation, Economic growth rate, Gross national income, Exchange rate, Net cash reserve, Total domestic debt, Balance of current transactions and transfers, Total surplus (deficit), Simultianeous equation model, Forecasting

\section{ABSTRACT}

Inflation is meant the overall and continuing rise in prices by the impact of internal or external variables, produced by excess demand about supply capacity. Problem of the study: The Egyptian economy has a decline in overall economic indicators, most importantly is the overall growth rate, compared with a rise in inflation, poverty, unemployment, the low production and the continuing deficit in the trade balance, and in general budget, which are negative indicators for the Egyptian economy. Therefore, the study is trying to explain and study the problem of inflation, its direct and indirect effects on overall growth rates in the Egyptian economy. Research Objectives: Identify the reality of growth rate in the Egyptian economy; identify what are inflation types and methods of measurement, measuring interaction relationships between both of inflation rates and growth rates in the Egyptian economy, determine factors afficting of both inflation and growth rates in Egypt, to work on indirect effect in these phenomena by afficting on those factors.

\section{Results and recommendations}

1-To study the effect of the most important variables of affected GDP at current and real prices in Egypt during the period (2003-2014): It turns out that study variables give effects on growth rate in real GDP at real prices consistent with eco- nomic logic, on the contrary effects of the growth rate of GDP at current prices.

2- Study interrelationships between the local annual growth rate at real and current prices and the annual inflation rate in Egypt during the period (2003-2014): It was concluded that data will be relied on real growth rate of GDP in its relations with inflation, where it is more logical from the economic point of view than the results of the GDP growth rate of GDP at current prices.

3- The relation between the inflation rate and growth rate GDP in real terms is negatively slope.

4- The results of the current economic model show that: The most important factors affecting in inflation rate and real growth rate in GDP are: First: Annual inflation rate in consumer prices $\overline{\left(X_{2}\right)}$, it has a negative significant statistically effect for both of annual growth rate of GDP at real prices\% $\left(X_{6}\right)$, net cash reserve $\left(X_{8}\right)$, and the balance of current transactions and transfers $\left(\mathrm{X}_{13}\right)$. And positive significant statistically effect for both of exchange rate of the dollar declared by the Central Bank $\left(X_{10}\right)$, and and the total surplus (deficit) $\left(X_{21}\right)$. Second: Annual growth rate of GDP at real prices $\%\left(X_{6}\right)$, it has a negative effect from, annual inflation rate in consumer prices $\left(\mathrm{X}_{2}\right)$, and the exchange rate of the dollar announced by the Central Bank $\left(X_{10}\right)$, while the effect was statistically significant positive for both of, net cash reserve $\left(\mathrm{X}_{8}\right)$, and the total surplus (deficit) $\left(\mathrm{X}_{21}\right)$.

5- Best method to forcast the main variables under study of inflation rate and the real growth rate of GDP is the use of the simutianeous equation model it takes into consideration all external variables affecting the internal variables under study. It was reached by forcasting both of the 
Inflation rates and real GDP growth rates, that the policies followed by floating exchange rate, which requires an impact on all variables to the hoped results of the floating of the Egyptian pound.

Therefore research recommends: to re-enter the Central Bank for determining the exchange rate of the Egyptian pound against other currencies, not directly to the currency exchange rate, but by indirect intervention through supply and demand control of the currency in Egyptian market against other currencies, by intervening in the market by selling and buying direct from banks, in addition to moving external variables affecting both inflation and real growth rates in Egypt to able to reach the resalts of simulitanuos equation model which takes into account all external variables related to the study variables.

\section{INTRODUCTION}

Inflation is the general and continuous rise in prices, by the impact of internal variables or external variables, that is, demand greater than supply. Inflation arises as a result the imbalance between production and consumption, exports and imports, savings and investment, agricultural land and population, and between government revenues and governmental expences, In addition to weak production capacities and the decrease in capital formation rates.

\section{Study problem}

The Egyptian macroeconomic indicators decline especially total growth rate, Vs height in Inflation rates, poverty and unemployment, and decrease in production. Continuous deficit in the trade balance and in general budget, Which are negative indicators on the Egyptian economy, So the study try to identify the direct and indirect effects of inflation on the overall growth rates in the Egyptian economy.

\section{Research Objectives}

1- Identify the reality of inflation and growth rate In the Egyptian economy.

2- Measure the substitution relationships between both of Inflation rates and growth rates in the Egyptian economy.

3- Identify factors afficting for both of Inflation rates and growth rates in the Egyptian economy, to try to make an indirect effect on these phenomenas.

\section{Methodology and data sources}

To find out the impact of inflation on Growth rates in the Egyptian economy, determinants of inflation rates, and forcasting those relationships through a simultanueous equations models, which includes all relationships between all various related variables, and try to develop a future vision for inflation and growth rates in the Egyptian economy.

The research is based on data published by the Ministry of Finance, the Central Bank of Egypt and the Central Agency for Public Mobilization and Statistics، As well as periodicals, publications, thesises and articles related to the subject research, as well as publications, books and articles from the Internet.

\section{Research importance}

Inflation is one of the major currently problems affecting the world economy, despite growing interest from economists to this phenomenon, but it is still a major controversy by economists across the world and the debate is going on the underlying causes of inflation, and its economic affects on the economic system and policy priorities to face this phenomenon, such as fiscal, monetary and trade policy, and their impact on productive sectors and on social strata.

Research depends on achieving its goals by try to configure a set of simultanueous equations models which are linked all the study variables to each other, this is so difficult to separate those variables in single equations, and deal with them independently of other equations, so the search tries to face of such interdependence in effect through an econometric simultaneous model.

\section{Theoretical framework}

It will be divided to inflation, growth rates, floating the Egyptian currency, the definition of simultanueous equations models used in research and the variables affecting inflation and growth rates.

\section{Definition of inflation, its types, its reasons and methods of facing it}

\section{Inflation types}

There are several definitions of inflation, "Inflation is the upward movement of prices characterized by self-continuing resulting from excess de- 
mand over supply capacity" or "inflation is the continuous rise in the overall level of prices of goods and services over time, Thus, inflation has two main elements: the general increase in prices (Inflation is not just a rise in the price of one or two goods, Because the rise may be offset by a decline in the prices of other goods, which entails the survival of the general level of prices fixed, But inflation is the general rise in the prices of the majority of basic goods and services), And a continuous rise in prices (inflation is a dynamic phenomenon whose danger lies in its continuing existence, In this regard, the differentiate between a one-time temporary increase and Lasting height for one time. It may also lead to some political crises such as wars, wealth or global unrest Led to a rise in the prices of some inputs such as energy prices and wages, Which leads to a rise in the prices of industrial products, but the rise in prices, which can be considered inflation is the continuous rise over time and for a long time) ${ }^{1}$.

\section{Different criteria on which different types of inflation are classified}

\section{In terms of state supervision of prices}

a- Open inflation: This is the rise in prices that there are no attempts to prevent or determine the speed of the government or economic institutions, and this type is also called explicit inflation, open inflation or free inflation.

b- Suppressed Inflation: The situation in which pressure is present (Direct government intervention) at the price level, and these pressures in the form of setting the upper limits of prices of various commodities to prevent the achievement of a real increase in the overall level of prices.

\section{2- In terms of strength of inflation}

a- Rapid inflation or hyperinflation: is the large increase in prices followed by a similar increase in wages, so the cost of production will increases and decrease profitability of business which lead to an increase in wages, thus, the economy is affected by Inflation: It is a strong inflation and takes place in a short period of time.

${ }^{1}$ Rihan M.K. 2014-2015, Macroeconomics, Faculty of Agriculture Ain Shams University, , Graduate Studies, Suez Canal University, Faculty of Environmental Agricultural Sciences, Arish, Department of Economics and Rural Development, 121 p. b- Slow or creeping inflation, It: Is a part of the rise in prices resulting from higher wages at a higher rate than the increase in production, which is gradual and slow gradual inflation combined with the natural forces of economic growth، but its continuation and collect its effects can lead to hyperinflation.

3- Spiral Inflation: Higher production costs arising from higher wages, and the increase of production costs lead to higher prices, leading the labour with demand for raising wages and so on. Because the increase in salaries is a part of the increase in production costs, which makes traders raise the prices of their products by money illusion, their nominal salaries, which they include at the end of the month, but this increase was accompanied by an increase in price, in other words, their real wages have not changed and their purchasing power has not increased, and perhaps even increased prices above the salary increase, they are undoubtedly worse after the increase in salaries, they return to demand another increase again, after they discovered the phenomenon of deceiving money, and their real consumption and purchasing power have not changed. Here is the phenomenon of "spiral inflation" which does not stop, this is a global phenomenon known and seen.

\section{4- In terms of inflation causes}

a- Demand Inflation: Due to the imbalance in the market, if the total supply is unable to cover total demand, which leading to an increase in the general price level. It should be noted that the rise in the general prices level resulting from higher aggregate demand will not lead to lower demand but to increase demand and so on.

b- Cost Inflation: It arises as a result of pressure by trade unions to raise wages.

\section{5- In terms of international economic relations}

a- Imported Inflation: This is due to the dependence of the State on goods and services imported from abroad, and therefore when the exporting country of these goods and services suffer from inflation this inflation is transferred to the domestic economy through goods and services imported.

b- Exported Inflation: The increase in prices due to the increase of reserves of central banks of cash dollars. 
6- Structural Inflation: It happens in developing countries, particularly, As a result of the inability of the productive apparatus to respond the changes in the structure of the national economy.

If demand for raw materials changes from developed countries for any reason this led to a shortage in developing countries from outcome of foreign currencies, And therefore their inability to get the needs of machines and equipment, Which leads to a lack of supply of goods and services.

7- Mixed demand, cost Inflation: The increase in demand may not be general in the economic structure, there may be an increase in demand in the products of a particular sector without other sectors. If the demand for a sector's products rises, the prices of these products will rise and therefore increase profit, this situation leads business owners in this sector to expand production. Therefore it can be said that general inflation or mixture may occur without a general increase in demand but as a result of excessive demand in one sector of the economic structure.

Inflation impacts: Serious concern due to the existence of inflation in economic and social impacts, Which can be accomplished as follows: Weaken the confidence of individuals in the currency, to weaken the incentive to save. The difference in the balance of payments, by increasing the demand for imports, decreasing the volume of exports, prices continue to rise leads to confusion in the implementation of projects, and the impossibility of determining the costs of their establishment, social injustice is a result of inflation, so it affects the fixed income holders and shareholders, inflation hinders the distribution of incomes and wealth, closes the wave of social and political tension and resentment necessary to advance social and economic development.

Inflation Treatment Policies: Inflation can be treated either by fiscal policy and monetary policy: It can be summarized definition and procedures of each of the previous policies:

First, monetary policy and its tools: Definition: Is that policy related to money and the banking system that affect the money supply, either by increasing or decreasing them. But the monetary policy against inflation, are based on reducing the amount of money shrinkage in bank credit, by the following tools:

1- Rate or Interest Rate: It is the price at which commercial banks deal with individuals. Commercial banks committed with the maximum limit for the year of interest determined by the Central Bank.

2- Discount Rate: This is the rate which central banks deal trade with commercial banks, which is slightly higher than interest rates

3- Legal reserve ratio: Which is the percentage that the Commercial Bank must keep from each deposit deposited in it in the form of liquid money in the central bank and there is no benefit for it.

4- Open Market Process: This is the central bank buying or selling government bonds from commercial banks with the aim of increasing its monetary reserves to enable it to borrow. Monetary policy instruments help control the amount of money supplied, either increased in the case of deflation, Or reduced in the case of inflation. So it is an important means to controlling inflation.

Economic Growth: Defined as an increase in the quantity of goods and services produced by a given economy, these commodities are produced using the main economic production factores: land, labor, capital and organization, It is also known as a positive change in the level of production of goods and services in a given country in a given period of time. The goal of any economy in the world is to achieve sustained economic growth; it is based on resource and income sustainability by creating industries that generate sustainable added value with preserving the environment and the rights of future generations.

\section{Floating exchange rate}

The Central Egypt Bank announced in Thursday (November 3rd, 2016) floating the Egyptian pound, As it reduced the exchange rate of the Egyptian currency from 8.88 pounds to one dollar to 13 pounds, As an indicative price, It will also give freedom to the market in determining the prices of buying and selling, Until the market balance on the real price. Leaving its pricing to the banks with the aim of eliminating the illegal market, which was found in Egypt several months ago due to pressure on the dollar.

The central bank also announced raise interest rate on deposits in Egyptian pounds to reach $14.75 \%$ and to $15.75 \%$ for loan. The central bank statement came to advise that "Decided to take several actions to correct the policy of trading foreign exchange through liberalization of exchange rates to give flexibility to banks operating in Egypt to set a price of buying and selling foreign exchange, In order to restore its circulation within the legal channels and completely end the parallel market of foreign exchange. 

on economic growth in Egypt

\section{*The theoretical framework of econometric models used in research}

The econometric model can be defined as a set of economic relations with links that are expressed in a mathematical form, There has been a growing interest in studying models in the recent period, This is due to the absence of individual equations in expressing the relationship between economic variables, In order to identify the nature of the relationship between these variables, and measure their mutual impact ${ }^{2}$.

The economic model also predicts the value of internal variables in the future in terms of other variables, And identify the value taken by an external variable to achieve its value for an internal variable, Which is very useful in the formulation of various economic policies of economic structure.

Components of the model: The economitric model consists of a set of mathematical equations, Which reflect the various relationships between the economic variables under study, In order to identify the nature of the relationship between those variables and the measurement its impact on mutual, These structural equations are called structural equations, their number varies from one model to another depending on the complexity of the problem and the variables affecting it and the objective of the study. Structural equations are divided into four types: behavioral equations: they explain the behavior of the consumer, product or importer, and definition equivalents: They are defined variables as unconditional definition, organizational Equations: It is using in clarification regulatory laws, technical Equations: It explains and explains the technical aspects

Variables used for model equations: Structure Equation are consists of two equal parties, it includes a number of variables, some know as Exogenous Variables: These are variables that are determined according to the forces outside the model, and Endogenous Variables: These are variables that can be explained and interpreted within the model.

It should be noted that the solution of any model is based on the fact that the number of equations in the model is equal to the number of internal variables in it, in order to arrive at unbiased estimates of the internal variables, it is necessary to use regression estimates for the reduced form rather than the individual solution of the structural

\footnotetext{
2Dominick, S. 1978. Schaum's Outline of Theory and
} Problems of Statistics and Econometrics, $103 \mathbf{p}$. equations. The reduced form is the equations derived from structural equations that take into account the requirement of unbiased estimates.

Econometric models: Simulitanious equation Models: A model in which the equilibrium value of one of its internal variables can not be determined without using all the equations contained in that one, that is, it exists relationship and reciprocal effect between those variables. Models of sequentially equations: These are the models in which the equilibrium values of their internal variables can only be determined sequentially for each value of the internal variable calculated in the calculation of the internal variable, and so on. Models of equations that are ostensibly not related: Consists of a set of equations that appear to be apparently unrelated, but are in fact linked to implicit reasons.

Discrimination or Definition: Structural equations can be distinguished through the structural form of the model by applying two conditions, order Condition, and rank Condition. So that the order Condition is tested first, the condition is necessary and not sufficient, but the rank Condition is a necessary and sufficient condition. The application of these two conditions we reach any of these equations complete identify, incomplete or redundant identify.

\section{Estimation methods of Simulitanious equations Models}

First, the statistical estimate for each equation alone: This method is characterized by estimating each equation of the model independently, and take into account information about the formula to be estimated only, so it named by Limited information methods, the most important of these methods: Ordinary least squares (OLS): Used in the case of consecutive equations, reduced form method, It is also named by Tow stage least square (2SLS): It is used in the case of equations over identify. All of this gets consistent and unbiased results.

Second, the statistical estimation of a set of equations at the same time: This method is characterized by estimating all equations of the model simultaneously (It takes all the information and constraints contained in the model equations into account when estimating any equation) so it named full Information methods, the most common methods of calculation is three stage least square (3SLS): It is used in the case of equations over identify without the existence of under identify 
equations in the model, all of these estimates get consistent and unbiased results ${ }^{3}$.

Variables affecting inflation and growth rates ${ }^{4}$; $\left(X_{1}\right)$ Time, $\left(X_{2}\right)$ The annual rate of inflation in consumer prices, which reflects in the research the consumer price index for the base year $2010=$ 100, $\left(X_{3}\right)$ Annual growth rate in GDP at current prices\%, $\left(\mathrm{X}_{4}\right)$ GDP at current prices (LE billion), $\left(X_{5}\right)$ Gross Domestic Product (GDP) in real prices (LE billion), $\left(\mathrm{X}_{6}\right)$ Annual growth rate of GDP at real prices\%, $\left(X_{7}\right)$ Local liquidity growth rate $M 2 \%,\left(X_{8}\right)$ Net cash reserve at end of period (\$ billion), $\left(X_{9}\right)$ Annual discount rate of the Central Bank\%, $\left(X_{10}\right)$ The dollar exchange rate announced by the Central Bank at the end of the period of purchase (pound/dollar), $\left(X_{11}\right)$ Total domestic debt(billion pounds), $\left(X_{12}\right)$ Net domestic debt of the government (billion pounds), $\left(X_{13}\right)$ Balance of current transactions and transfers (billion dollars), $\left(X_{14}\right)$ trade balance (billion dollars), $\left(X_{15}\right)$ The total value of commodity exports (billion dollars), $\left(X_{16}\right)$ The total value of commodity imports (billion dollars), $\left(X_{17}\right)$ services balance (billion dollars), $\left(X_{18}\right)$ The balance of receipts (billion dollars), $\left(X_{19}\right)$ Balance of payments (billion dollars), $\left(X_{20}\right)$ balance transfers (billion dollars), $\left(X_{21}\right)$ Total surplus (deficit) (billion dollars), $\left(\mathrm{X}_{22}\right)$ External debt at the end of period (billion dollars).

\section{DISCUSS RESEARCH RESULTS}

The Time Trends of Study Variables in the Egyptian Economy during the Period (20032014)

The linear mathematical form was used to Discuss time trends for all study variables. The following table shows these statistical results divided into four groups according to their general time trend: The first group: Variables with an increasing general trend and have a significant increase with time, Which is: annual inflation rate in consumer prices $\left(X_{2}\right)$, Annual growth rate in GDP with current prices\% $\left(\mathrm{X}_{3}\right)$, GDP with current prices (billion pounds) $\left(X_{4}\right)$, Gross national product in real prices (billion pounds) $\left(X_{5}\right)$, The dollar exchange rate declared by the Central Bank at the end of the period of purchase (Piaster/dollar) $\left(\mathrm{X}_{10}\right)$, domestic debt for

\footnotetext{
${ }^{3}$ Rihan, M.K. 1983. Econometrics, Quantitative methods, Abu. Dhupia, Univ., of U.A.E..

${ }^{4}$ Annual Reports, Monthly analysis bulletins, Economic research sector, Central bank of Egypt, Miscellaneous numbers, 2003-2015.
}

the total year (billion pounds) $\left(X_{11}\right)$, net domestic debt of the government (billion pounds) $\left(X_{12}\right)$, Total value of commodity exports (billion dollars) $\left(X_{15}\right)$, the total value of commodity imports (billion dollars) $\left(X_{16}\right)$, balance of receipts (billion dollars) $\left(X_{18}\right)$, balance of payments (billion dollars) $\left(X_{19}\right)$, Balance transfers (billion dollars) $\left(\mathrm{X}_{20}\right)$, external debt at the end of period (Billion Dollars) $\left(\mathrm{X}_{22}\right)$.

The second group: The variables with insignificant general increasing trend rates with time, which is: The total value of commodity imports (billion dollars) $\left(\mathrm{X}_{16}\right)$, which indicates the stability of this variable around the mean during the study period.

Third group: It includes variables with significant general decreasing trend rates with time, Which is: annual growth rate of GDP at real prices\% $\left(X_{6}\right)$, Net cash reserve at end of period $(\$$ billion) $\left(X_{8}\right)$, Annual discount rate of the central bank\% $\left(X_{9}\right)$, Balance of current transactions and transfers (billion dollars) $\left(\mathrm{X}_{13}\right)$, Balance of trade (billion dollars) $\left(\mathrm{X}_{14}\right)$, Total surplus (deficit) (billion dollars) $\left(\mathrm{X}_{21}\right)$.

Fourth Group: The variables with insignificant general decreasing trend rates with time, which is: Local liquidity growth rate $M 2 \%\left(X_{7}\right)$, Balance of services (billion dollars) $\left(X_{17}\right)$, which also means the stability of these variables around the mean during the study period.

Effect of study macro variables on the annual inflation rate in Egypt during the period (20032014)

The results of the equations for measuring the effect of the variables of the study on the annual inflation rate in Egypt, the Table (2) is summarized these results, by dividing it into four groups according to the effect of each of these factors on the annual inflation rate in Egypt during the study period:

The first group: Including variables with increasing statistically significant effect on the rate of inflation in Egypt, Which include: Annual growth rate of GDP at current prices (X3\%), GDP at current prices (billion pounds) (X4), Gross national product in real prices (billion pounds) (X5), Net cash reserve at end of period ( $\$$ billion) $(X 8)$, The dollar exchange rate declared by the Central Bank at the end of the period of purchase (pound/ dollar) (X10), Domestic debt for the total year (billion pounds) (X11), Net domestic debt of the government (billion pounds) (X12), The total value of commodity exports (billion dollars) (X15), Balance 
Table 1. The general time trend of the macro study variables in the Egyptian economy during the period (2003-2014)

\begin{tabular}{|c|c|c|c|c|c|}
\hline \multicolumn{3}{|c|}{$\begin{array}{l}\text { 1-Variables with significant statistically } \\
\text { increasing with time }\end{array}$} & \multicolumn{3}{|c|}{$\begin{array}{l}\text { 2-Variables with insignificant statistically } \\
\text { increasing with time }\end{array}$} \\
\hline Variable & $\begin{array}{c}\text { Annual rate of } \\
\text { change }\end{array}$ & Measure unit & Variable & $\begin{array}{l}\text { Annual rate of } \\
\text { change }\end{array}$ & Measure unit \\
\hline$X_{2}$ & 2.30 & $\%$ & $X_{16}$ & 0.20 & Billion dollar \\
\hline$X_{3}$ & 0.20 & $\%$ & \multicolumn{3}{|c|}{$\begin{array}{c}\text { 3-Variables with significant statistically } \\
\text { decreasing with time }\end{array}$} \\
\hline $\mathrm{X}_{4}$ & 20.30 & Billion pounds & Variable & $\begin{array}{c}\text { Annual rate of } \\
\text { change }\end{array}$ & Measure unit \\
\hline$X_{5}$ & 16.55 & Billion pounds & $\mathrm{X}_{6}$ & $0.12-$ & $\%$ \\
\hline$X_{10}$ & 2.31 & Piaster/Dollars & $\mathrm{X}_{8}$ & 281.08- & Billion dollar \\
\hline $\mathrm{X}_{11}$ & 32.67 & Billion pounds & $X_{9}$ & $0.01-$ & \\
\hline $\mathrm{X}_{12}$ & 28.88 & Billion pounds & $X_{13}$ & $0.16-$ & Billion dollar \\
\hline$X_{15}$ & 0.22 & Billion dollar & $X_{14}$ & $0.43-$ & Billion dollar \\
\hline$X_{16}$ & 0.20 & Billion dollar & $X_{21}$ & $0.08-$ & Billion dollar \\
\hline$X_{18}$ & 0.12 & Billion dollar & \multicolumn{3}{|c|}{$\begin{array}{l}\text { 4-Variables with insignificant statistically } \\
\text { decreasing with time }\end{array}$} \\
\hline$X_{19}$ & 0.26 & Billion dollar & Variable & $\begin{array}{c}\text { Annual rate of } \\
\text { change }\end{array}$ & Measure unit \\
\hline $\mathrm{X}_{20}$ & 0.34 & Billion dollar & $\mathrm{X}_{7}$ & $0.04-$ & $\%$ \\
\hline$x_{22}$ & 0.32 & Billion dollar & $X_{17}$ & $0.05-$ & Billion dollar \\
\hline
\end{tabular}

Source: Economic Journal, Annual Reports, Monthly Analysis Bulletins, Economic Research Sector, Central Bank of Egypt, Miscellaneous Numbers.

Table 2. Effect of macro variables on the annual inflation rate in Egypt during the period (2003-2014)

\begin{tabular}{|c|c|c|c|c|c|}
\hline \multicolumn{3}{|c|}{$\begin{array}{l}\text { 1-Variables with significant statistically } \\
\text { increasing with inflation rate in Egypt }\end{array}$} & \multicolumn{3}{|c|}{$\begin{array}{l}\text { 2-Variables with unsignificant statistically } \\
\text { increasing with inflation rate in Egypt }\end{array}$} \\
\hline Variable & $\begin{array}{l}\text { Annual rate of } \\
\text { change }\end{array}$ & Measure unit & Variable & $\begin{array}{l}\text { Annual rate of } \\
\text { change }\end{array}$ & Measure unit \\
\hline$X_{3}$ & 3.57 & $\%$ & $\mathrm{X}_{16}$ & 0.09 & Billion dollar \\
\hline $\mathrm{X}_{4}$ & 0.07 & Billion pounds & \multicolumn{3}{|c|}{$\begin{array}{l}\text { 3-Variables with significant statistically } \\
\text { decreasing with inflation rate in Egypt }\end{array}$} \\
\hline$X_{5}$ & 0.06 & Billion pounds & Variable & $\begin{array}{c}\text { Annual rate of } \\
\text { change }\end{array}$ & Measure unit \\
\hline $\begin{array}{l}X_{8} \\
X_{10} \\
X_{11} \\
X_{12} \\
X_{15}\end{array}$ & $\begin{array}{l}0.01 \\
0.39 \\
0.07 \\
0.07 \\
1.57\end{array}$ & $\begin{array}{c}\text { Billion dollar } \\
\text { Piaster/Dollars } \\
\text { Billion pounds } \\
\text { Billion pounds } \\
\text { Billion dollar }\end{array}$ & $\begin{array}{l}X_{6} \\
X_{9} \\
X_{13} \\
X_{14} \\
X_{17}\end{array}$ & $\begin{array}{l}11.19- \\
10.71- \\
8.09- \\
2.43- \\
3.07-\end{array}$ & $\begin{array}{c}\text { \% } \\
\% \\
\text { Billion dollar } \\
\text { Billion dollar } \\
\text { Billion dollar }\end{array}$ \\
\hline$X_{18}$ & 1.16 & Billion dollar & \multicolumn{3}{|c|}{$\begin{array}{l}\text { 4-Variables with unsignificant statistically } \\
\text { decreasing with inflation rate in Egypt }\end{array}$} \\
\hline$X_{19}$ & 3.79 & Billion dollar & Variable & $\begin{array}{c}\text { Annual rate of } \\
\text { change }\end{array}$ & Measure unit \\
\hline $\begin{array}{l}X_{20} \\
X_{22} \\
\end{array}$ & $\begin{array}{l}3.88 \\
5.43 \\
\end{array}$ & $\begin{array}{l}\text { Billion dollar } \\
\text { Billion dollar }\end{array}$ & $\begin{array}{l}\mathrm{X}_{7} \\
\mathrm{X}_{21} \\
\end{array}$ & $\begin{array}{l}0.88- \\
2.93-\end{array}$ & $\begin{array}{c}\% \\
\text { Billion dollar } \\
\end{array}$ \\
\hline
\end{tabular}

Source: Economic Journal, Annual Reports, Monthly Analysis Bulletins, Economic Research Sector, Central Bank of Egypt, Miscellaneous Numbers 
of receipts (billion dollars) (X18), Balance of payments (billion dollars) (X19), Balance transfers (billion dollars) (X20), External Debt at the end of Period (Billion Dollars) (X22).

The second group: Including variables with increasing insignificant effects on the inflation rate in Egypt, Which are: Total value of commodity imports (billion dollars) (X16).

Third group: Including variables with decreasing significant effect on the inflation rate in Egypt, Which are: Annual growth rate of GDP at real prices ( $\%$ X6), Annual discount rate of the central bank\% (X9), Balance of current transactions and transfers (billion dollars) (X13), Balance of trade (billion dollars) (X14), Balance of services (billion dollars) (X17).

Fourth Group: Including variables with decreasing insignificant effect on the inflation rate in Egypt, Which are: Local liquidity growth rate M2 (X7), total surplus (deficit) (billion dollars) (X21).

\section{Effect of the most important macro variables on GDP at current and real prices in Egypt dur- ing the period (2003-2014)}

In Table (3), Results of equations to measuring the effect of macro variables on GDP at current and real prices in Egypt during the period (20032014): Those results divide to five groups according to the impact of each of these factors on the annual inflation rate in Egypt during the study period:

First group: For comparison, the effect of inflation on the annual growth rate of GDP at real prices and current prices in Egypt during the period (2003-2014), It was found that the increase in inflation rates had a statistically significant negative effect on growth in GDP at current and real prices in Egypt during the study period.

Second group: Includes variables with increasing statistically significant effect on annual GDP growth rate at real and current prices in Egypt, Which: Effect of, net cash reserve at the end of the period (X8), balance of current transactions and transfers (billion dollars) (X13), and balance of trade balance (X14) Increasing statistically significant effect on the growth rate of GDP in real terms which is consistent with economic Logic. On the contrary, the effect of these variables on the overall growth rate at current prices was negative statistically significant, which is not consistent with economic logic. As for both variables, local liquidity growth rate $\mathrm{M} 2 \%(\mathrm{X} 7)$, and the total surplus (deficit) (X21) provid to have a increase statistically significant effect on the real GDP growth rate, which is consistent with economic logic, the increase in these variables had a negative unsignificant statistically effect on the growth rate of GDP at current prices, which is not consistent with economic logic. Finally, the changes in the balance of services balance (X17) have a statistically significant effect on the rate of GDP growth in real terms, which is consistent with economic logic, while the effect of the increase in this variable has an increasing effect that is not statistically significant, which revolves around the medium arithmetic, which is not consistent with economic logic.

Third group: Includes variables with increasing insignificant statistically effect on annual GDP growth rate at real and current prices in Egypt: This group includes the variable annual discount rate of the Central Bank (X9\%), the increase in this variable over time has a positive unsignificant statistically effect on the growth rate of GDP in real terms, and negative unsignificant statistically impact on the rate of growth at current prices, that is, it revolves around its arithmetic mean.

Fourth group: Includes variables with decreasing significant effect on annual GDP growth rate at real and current prices in Egypt: The effect of Annual inflation rate with consumer prices (which reflects in the study the consumer price index for the base year $2010=100)(X 2)$, total local debt for the year (X11), net domestic debt of the government (X12), the balance of payments (X19), And the External Debt at the end of the Period (X22). These variables was negative and was significant effect on the rate of growth of domestic product in real prices, which is consistent with economic logic, on the contrary, the effect of these variables on the overall growth rate at current prices is significant, which is not consistent with economic logic. As for the variable of the dollar exchange rate announced by the Central Bank, (purchase price) (pound/ dollar) (X10) have statistically significant effect on the growth rate of GDP in real terms, against an increasing insignificant statistically effect on the growth rate of GDP at current prices. 
Table 3. The statistical analysis between the annual growth rate of GDP at real and current prices and each of macro study variables in Egypt during the period (2003-2014)

\begin{tabular}{|c|c|c|c|c|c|c|c|c|c|c|}
\hline \multirow[t]{3}{*}{ Variable } & \multicolumn{5}{|c|}{$\begin{array}{l}\text { Annual growth rate in real GDP \% } \\
\qquad(\mathrm{X6})\end{array}$} & \multicolumn{5}{|c|}{$\begin{array}{c}\text { Annual growth rate in GDP at current } \\
\text { prices ( } \% \text { X3) }\end{array}$} \\
\hline & \multicolumn{5}{|c|}{ Equations } & \multicolumn{5}{|c|}{ Equations } \\
\hline & $\alpha$ & $\beta$ & $(\mathrm{t})$ & $\mathbf{R}^{2}$ & $F$ & $\alpha$ & $\beta$ & $(\mathrm{t})$ & $\mathbf{R}^{2}$ & $F$ \\
\hline
\end{tabular}

Group 1: Comparison of the effect of inflation on both the annual growth rate of GDP at real and current prices in Egypt during the period 2003-2014

\begin{tabular}{|c|c|c|c|c|c|c|c|c|c|c|}
\hline \\
\hline$X_{6}$ & ----- & ---- & ---- & ---- & --- & 14.89 & $0.52-$ & $1.70-$ & 0.06 & 2.89 \\
$X_{3}$ & 6.19 & $0.11-$ & $1.70-$ & 0.06 & 2.89 & --- & ---- & ---- & ---- & ---- \\
\hline
\end{tabular}

Group 2: Factors with a positive significant effect on the annual growth rate of GDP in real prices and comparing them to current prices in Egypt during the period 2003-2014

\begin{tabular}{|c|c|c|c|c|c|c|c|c|c|c|}
\hline $\mathrm{X}_{7}$ & 3.94 & 0.01 & 1.43 & 0.04 & 2.04 & 13.51 & $0.13-$ & $0.87-$ & 0.02 & 0.79 \\
$\mathrm{X}_{8}$ & 0.72 & 0.0003 & 4.54 & 0.31 & 20.57 & 23.91 & $0.001-$ & $4.46-$ & 0.30 & 19.85 \\
$\mathrm{X}_{13}$ & 5.32 & 0.52 & 6.42 & 0.47 & 41.19 & 11.55 & $0.81-$ & $4.03-$ & 0.26 & 16.21 \\
$\mathrm{X}_{14}$ & 6.69 & 0.14 & 4.39 & 0.30 & 19.30 & 9.41 & $0.21-$ & $2.98-$ & 0.16 & 8.87 \\
$\mathrm{X}_{17}$ & 3.64 & 0.21 & 2.24 & 0.10 & 5.01 & 11.41 & 0.19 & 0.92 & 0.02 & 0.89 \\
$\mathrm{X}_{21}$ & 4.73 & 0.33 & 4.72 & 0.33 & 22.29 & 12.43 & $0.01-$ & $0.05-$ & 0.0001 & 0.002 \\
\hline
\end{tabular}

Group 3: Factors with a positive insignificant effect on the annual growth rate of GDP in real prices and comparing them to current prices in Egypt during the period 2003-201:

\begin{tabular}{|l|l|l|l|l|l|l|l|l|l|l|}
$\mathrm{X}_{9}$ & $0.16-$ & 0.52 & 1.81 & 0.03 & 1.39 & 14.29 & 0.20 & $0.21-$ & 0.001 & 0.04 \\
\hline
\end{tabular}

Group 4: Factors with a negative significant effect on the annual growth rate of GDP in real prices and comparing them to current prices in Egypt during the period 2003-2014

\begin{tabular}{|c|c|c|c|c|c|c|c|c|c|c|}
\hline $\mathrm{X}_{2}$ & 9.65 & $0.05-$ & $8.06-$ & 0.59 & 64.96 & 5.42 & 0.07 & 4.10 & 0.27 & 16.79 \\
$\mathrm{X}_{10}$ & 15.88 & $0.02-$ & $3.54-$ & 0.21 & 12.54 & 12.14 & 0.001 & 0.04 & 0.0003 & 0.001 \\
$\mathrm{X}_{11}$ & 7.93 & $0.003-$ & $6.78-$ & 0.50 & 46.02 & 0.07 & 0.005 & 3.51 & 0.21 & 12.34 \\
$\mathrm{X}_{12}$ & 7.47 & $0.004-$ & $6.33-$ & 0.47 & 40.01 & 8.79 & 0.005 & 3.26 & 0.19 & 10.62 \\
$\mathrm{X}_{19}$ & 6.09 & $0.02-$ & $3.84-$ & 0.24 & 14.74 & 9.96 & 0.38 & 3.25 & 0.19 & 10.56 \\
$\mathrm{X}_{22}$ & 13.21 & $0.25-$ & $4.89-$ & 0.34 & 23.87 & $2.47-$ & 0.43 & 3.77 & 0.24 & 14.20 \\
\hline
\end{tabular}

Group 5: Factors with a negative insignificant effect on the annual growth rate in real GDP in real terms and comparing them to current prices in Egypt during the period 2003-2014

\begin{tabular}{|l|l|l|l|l|l|l|l|l|l|l}
$\mathrm{X}_{18}$ & 5.48 & $0.06-$ & $1.08-$ & 0.02 & 1.17 & 9.73 & 0.21 & 1.97 & 0.08 & 3.86 \\
\hline
\end{tabular}

Source: Economic Journal, Annual Reports, Monthly Analysis study, Economic Research Sector, Central Bank of Egypt, Miscellaneous Numbers. 
Fifth group: Includes variables with decreasing insignificant statistically effect on annual GDP growth rate at real and current prices in Egypt: This group includes Balance of receipts (billion dollars) (X18), this variable increases with time with negative insignificant effect on the growth rate of GDP in real prices, and an increasing significant statistically effect on the rate of growth at current prices.

Summarize the results: From the above results conclude that the macro variables of the study give an effect on the rate of growth in GDP at real prices consistent with economic logic, as comparied with their effects on the growth rate of GDP at current prices.

Interrelations between the local annual growth rate at real and current prices and the annual inflation rate in Egypt during the period (20032014)

To determine the shape of the correlation between the local annual growth rate in real and current prices on the one hand and the annual inflation rate on the other in Egypt during the period (2003-2014), the study aimed at estimating the simple regression equations between these variables in order to arrive the form of these relations. The results recorded in the following table, it is clear that the annual rate of growth in real GDP in real terms $\%$ has a statistically significant negative effect on inflation during the study period, the annual rate of growth rate in real GDP increases by $1 \%$, the inflation rate decreases by $11.19 \%$. The effect of the inflation rate on the annual rate of growth in GDP at real prices\%, it has taken a twoway significant statistically effect, as the inflation rate increased by $1 \%$, the annual growth rate in real GDP decreases by $0.05 \%$, values of $R^{2}$ and $F$ are equivalent in this equations, By comparing the results of equations 1,2 the effect is reciprocal between inflation rate and annual growth rate of GDP in real terms. The simple regression equations between the two variables did not achieve which of them is the main effect in the other variable.

It is also clear that the annual rate of growth rate in GDP at current prices has a statistically significant effect on inflation during the study period, as the annual rate of growth rate in GDP at current prices increases by $1 \%$, the rate of inflation increases by $3.57 \%$. When studying effect of inflation rate on annual growth rate in GDP at current prices\%, it took a positive statistically significant relation, where the inflation rate increases by $1 \%$ the annual growth rate GDP is increasing by current prices by $0.07 \%$, values of $R^{2}$ and $F$ are equivalent in this equations, By comparing the results of equations 3,4 the effect is reciprocal (twoways) between inflation rate and annual growth rate of GDP in Current terms. The simple regression equations between the two variables did not achieve which of them is dependent or independent variable in the estimated equation.

However, the results of the mutual effect between the annual growth rate in real prices GDP and inflation rate during the study period it reverse significant relationship, which is consistent with economic logic. In contrast to the results of the mutual effect between the annual growth rate in GDP at current prices and inflation during the study period, Where it took a positive significant effect and this result is illogical statistically, Where the annual growth rate of GDP in real prices and the grade of its effect or affected at the rate of inflation during the study period, Through several attempts to enter other independent variables to determine the degree of influence of each of these variables on the other.

Summarize the results: The search will therefore depend on data real growth rate of GDP in its relations with inflation as it is more logical than the economic point of view of its counterpart to the results of gross growth rates at current prices of GDP.

Simutianeous equation model For mutual relationship between Inflation and local annual growth rate at real prices in Egypt during the period (2003-2014)

The estimation of the econometric model of multiple equations is relatively more difficult compared to the single equation models; this is because of the need for many stages and the many steps starting from the description of economic relations (According to economic logic) then determine the most important variables to be used according to the matrix of simple correlation coefficients, Then select the best mathematical forms that will be used in statistical analysis, This is followed by preparing the data to calculate the model equations, And determine the degree model identification, and the most suitable method for estimating, Due to the many variables used in the research, it has gone to do many alternatives In light of the economic theory and the available variables, has been done many of permutations and combinations between variables in light of economic and statistical significant, to obtain equations for the model of the problem to be used for forecasting. 
Table 4. Interrelationships between the local annual growth rate at real and current prices on the one hand and the annual inflation rate on the other in Egypt during the period 2003-2014:

\begin{tabular}{|c|l|c|l|l|}
\hline & Study variables & The equation & $\mathrm{R}^{2}$ & $\mathrm{~F}$ \\
\hline 1 & $\begin{array}{l}\text { Inflation rate }\left(\mathrm{X}_{2}\right) \text { is a function of the annual growth } \\
\text { rate in real GDP \% }\left(\mathrm{X}_{6}\right)\end{array}$ & $\begin{array}{c}\mathrm{X} 2=146.84-11.19 \\
(-8.06)\end{array}$ & 0.59 & 64.9 \\
\hline 2 & $\begin{array}{l}\text { Annual growth rate of GDP of real prices \% }\left(\mathrm{X}_{6}\right) \text { Func- } \\
\text { tion in inflation rate }\left(\mathrm{X}_{2}\right)\end{array}$ & $\begin{array}{c}\mathrm{X}_{6}=9.65-0.05 \mathrm{X}_{2} \\
(-8.06)\end{array}$ & 0.59 & 64.9 \\
\hline 3 & $\begin{array}{l}\text { Inflation rate }\left(\mathrm{X}_{2}\right) \text { Function of annual growth rate in } \\
\text { GDP at current prices \% }\left(\mathrm{X}_{3}\right)\end{array}$ & $\begin{array}{c}\mathrm{X}_{2}=49.20+3.57 \mathrm{X}_{3} \\
(4.10)\end{array}$ & 0.27 & 16.7 \\
\hline 4 & $\begin{array}{l}\text { Annual growth rate of GDP at current prices\% }\left(\mathrm{X}_{3}\right) \\
\text { Function of inflation rate }\left(\mathrm{X}_{2}\right)\end{array}$ & $\begin{array}{c}\mathrm{X}_{3}=5.42+0.07 \mathrm{X}_{2} \\
(4.10)\end{array}$ & 0.27 & 16.7 \\
\hline
\end{tabular}

source: Economic Journal, Annual reports, Monthly analysis bulletins, Economic Research Sector, Egyptian Central Bank, Miscellaneous bulletins.

Statistical analysis for the econometric model of the interrelationship between inflation and the annual growth rate at real prices in Egypt during the period 2003-2014

The interrelationship economic relations between inflation and the local annual growth rate at real prices in Egypt during the period (2003-2014) can be determined and characterized in two main relations, which can be characterized as follows:

1- Inflation function: Take the following format:

$$
X_{2}=f\left(X_{6}, X_{8} X_{10}, X_{11}, X_{13}\right)
$$

2-Local annual growth rate at real prices function:

Take the following format:

$$
X_{6}=f\left(X_{2}, X_{8}, X_{10}, X_{21}\right)
$$

Where: $\mathrm{X}_{2}$ : The annual rate of inflation in consumer prices, which is calculated with consumer price indices for the base year $2010=100$.

$\mathrm{X}_{6}$ : Annual growth rate of GDP at real prices\%.

$\mathrm{X}_{8}$ : Net cash reserve at the end of the year (billion dollars).

$\mathrm{X}_{10}$ : The dollar exchange rate declared by the Central Bank at the end of the year of purchase (pounds/ dollar).

$\mathrm{X}_{11}$ : Total domestic debt (billion pounds).

$\mathrm{X}_{13}$ : Balance of current transactions and transfers (billion dollars).

$\mathrm{X}_{21}$ : Total surplus (deficit) (billion dollars).
Model Variables: From the previous presentation of the variables that ingredient the two functions, these variables can be classified into two main parts

First: Endogenous Variables: These are the variables which can estimate its equilibrium values from the model, which is:

1-The annual inflation rate in consumer prices, which is represented in the study by the consumer price index for the base year $2010=100\left(X_{2}\right)$.

2- Annual growth rate of GDP at real prices $\%\left(X_{6}\right)$. Second: Exogenous Variables: These are variables which can determined outside the model, which are as follows:

1 - Net cash reserve (billion dollars) $\left(X_{8}\right)$.

2- The dollar exchange rate declared by the Central Bank at the end of the year (pound/ dollar) $\left(\mathrm{X}_{10}\right)$.

3- Domestic Gross Domestic Debt (EGP) (billion dollar) $\left(\mathrm{X}_{11}\right)$.

4- Balance of current transactions and transfers (billion dollars) $\left(\mathrm{X}_{13}\right)$.

5- Total surplus (deficit) (billion dollars) $\left(\mathrm{X}_{21}\right)$.

Under the different combinations of the two main functions of the study to the simultianeous equation model, the study has made many trails in order to determine the best fitting equations from the econometric point of view, the simultianeous equation model is the best model to explain the variables of study due to the two ways effects between them, this form of the model gaves satisfactory results in terms of economic, and statistical logic, the study make many trails to test the relationships between the study variables, including simple relationships among the variables studied in the model and the variables that should be exclud- 
ed to avoid statistical problems of estimating model equations, Since the equations of the model is over Identified, the research was directed at using the two stage least squares (2SLS), as it is the best way to find logical economically and statistically results from the model equations.

Results of statistical estimation of the simultianeous equation model

It is clear from the results of the statistical estimation of the current simultianeous equation model which have over Identified equations; therefore, tow stage least square method (2SLS) has the most appropriate methods to be used to estimate model results, The results of the analysis were as follows:

1- Inflation equation: The factors affecting the rate of inflation were represented in: The annual GDP growth rate at real prices has a negative impact on the inflation rate, where it is

The increase in local real GDP growth rate by $1 \%$ make decreased rate of inflation by $1.52 \%$ per year, and the relationship came negative statistically significant between both net cash reserve at end of the year (\$ billion), the balance of current transactions and transfers (billion dollars) from one side and inflation rate in Egypt in the same year, where the increasing of those variables by one unit, the inflation rate will decreasing by 0.001 ,
$1.133 \%$ respectively. While the relationship is increasing positive statistically significant between both of the dollar exchange rate declared by the central bank at the end of the year (pound/ dollar), domestic debt and inflation rate in Egypt in the end of the year during the study period, where the increase in both of these variables by one unit the Egyptian inflation rate will increasing by $0.041 \%$ and $0.53 \%$ units respectively.

2- The equation of the annual growth rate of GDP in real terms\%: Were the factors affecting it represented in: Inflation rate has a negative impact on the annual growth rate GDP in real terms, where the increase in inflation rate by $1 \%$ produces decrease in annual growth rate of GDP in real terms by $0.1 \%$ per year. The relationship came negative statistically significant between dollar exchange rate declared by the central bank the end of year (pound/ dollar) and annual growth rate of GDP in real terms in Egypt during study period, where it is increase in dollar exchange rate declared by the central bank by one unit lead to decreases in growth rate of about 0.005 units per year. While the relationship came statistically positive significant between net cash reserve at end of the year ( $\$$ billion), total surplus (deficit) (billion dollars) and annual growth rate of GDP at real prices, where the increaseing both of those variables by one unit growing annual growth rate of GDP in real terms $\%$ by $0.0003 \%$ and 0.2 units on an annual basis.

Table 5. Statistical Estimation of the factors afficting Inflation Rate and Local Annual Growth Rate by Real Prices in Egypt during the Period (2003-2014)

\begin{tabular}{|c|c|c|c|}
\hline Study variable & equation & $\mathbf{R}^{2}$ & $\mathbf{F}$ \\
\hline Inflation rate $\left(X_{2}\right)$ & $\begin{array}{r}X_{2}=92.37-0.001 X_{8}-1.52 X_{6}+0.041 X_{10}-1.133 X_{13}+0.053 X_{11} \\
(-2.86) \quad(-2.96)\end{array}$ & 0.92 & 425.30 \\
\hline $\begin{array}{l}\text { Annual growth rate of } \\
\text { GDP in real terms } \%\left(X_{6}\right)\end{array}$ & $\begin{array}{c}X_{6}=14.8+0.0003 X_{8}+0.2 X_{21}-0.1 X_{2}-0.005 X_{10} \\
(3.34) \quad(4.23) \quad(-6.26)\end{array}$ & 0.76 & 33.58 \\
\hline
\end{tabular}

Source: Economic Journal, Annual Reports, Monthly Analysis Bulletins, Economic Research Sector, Central Bank of Egypt, Miscellaneous Numbers.

Summarize the results: The results of the simultianeous equation model were determined the factors affecting both Inflation rate and real GDP growth rate in Egypt, They are represented in:

First: Annual inflation rate in consumer prices (Which is represented in the study by the consumer price index for the base year $2010=100)\left(X_{2}\right)$, it has a negative statistically significant effect on both the annual growth rate of GDP at real prices\%
$\left(X_{6}\right)$ And net cash reserve $\left(X_{8}\right)$, And the balance of current transactions and transfers (billion dollars) $\left(X_{13}\right)$. While the effect was positive statistically significant for exchange rate of the dollar declared by the Central Bank at the end of the year (pound/ dollar) $\left(X_{10}\right)$, and the total surplus (deficit) $\left(X_{21}\right)$.

Second: Annual growth rate of GDP at real prices\% $\left(X_{6}\right)$ it has a negative statistically significant effect for annual inflation rate in consumer 
prices $\left(X_{2}\right)$, and the exchange rate of the dollar announced by the Central Bank (pound/ dollar) $\left(X_{10}\right)$. While the effect was positive statistically significant for net cash reserve $\left(X_{8}\right)$, and the total surplus (deficit) $\left(\mathrm{X}_{21}\right)$.

\section{Forecasting model variables until 2025}

Forecasting the behavior of economic phenomena one of the most important economic objectives, whereas forecast is just a quantitative estimation for the expected values of dependent variables in the future based on what is available information about the past and the present, Forecasting is assumed that the behavior of economic phenomena in the future it is only an extension for the behavior of these phenomena in the recent past, and then sudden changes occur not expected probably to lead uncertainty of scientific predictions of the future of economic phenomena, In this regard to differentiate between point forcasting and forcasting by period, the point prediction means to predict one value for the dependent variable in each future period, The forcasting period With a certain range. The first means forecast with dependent variable values in an available data period this provides an opportunity to ascertain the validity of expectations and compare them with actual data available, The second forecast with the dependent variable values in future periods which have no available data to dependent variable forecasting methods vary when different models used. There is a scientific forecast using the single equation model ${ }^{5}$, there is scientific forecast using a multi-equation model, which will focus in this research.

To be sure of the credibility of parameters estimated by the estimated model from the economic point of view and statistical view, Keeps the ability of the model to predict using a test of inequality coefficient Theil $(U)^{6}$.

$$
U=\frac{1 / N \sum\left(\hat{Y}_{t}-Y_{t}\right)^{2}}{\sqrt{1 / N \sum \hat{Y}_{t}^{2}} \sqrt{1 / N \sum Y_{t}^{2}}}
$$

\footnotetext{
${ }^{5}$ Abeer A. Qenaoui, 2003. Economics of the Use of Chemical Fertilizers and Pesticides in Egyptian Agric., Ph.D. Thesis, Dept. of Agric. Economics, Fac. of Agric., Ain Shams Univ., Cairo, 276 p.

${ }^{6}$ Theil, H. 1961. "Economic Forecasts and Policy" $2^{\text {nd }}$ ed North - Holland, Publishing Company, Amsterdam, 89 p.
}

Where: $Y$ : The actual value of the dependent variable, $\hat{Y}$ : The estimated value of the dependent variable, N: Observations, T: Time.

$U$ ranges from zero to one, the closer to zero, and the more ability of the model to forecasting, vice versa, In other words, if $U=$ zero, this indicates the great ability to the model in forecasting, If $U=1$ this refers to the situation in which the forecasting of the dependent variable is fixed over time, the higher the value of $(U)$ than the one evidence that's the low efficiency of the model to predict, The following table shows Theil test, which indicates that the model has a great ability to use in forecasting.

\section{Forecasting for the rate of inflation and the real annual growth rate in Egypt until 2025}

The behavior of the variables studied has been forecasted by following three different methods, which will then be compared to their best predictors of these variables. The three methods that the study has been adopted are as follows:

First: Forecasting by using the general time trend: It will depend on the time factor only in forecasting the variables studied until 2025. These variables show their effect together only through the indirect effect of the variable that represents time in the time trend equations.

Second: Forecasting the variable of the study by multiregresstion equation contains both time trend and dollar exchange rate until 2025.

Third: Forecasting the use of the simultanueous equation model: This is done by the following steps:

1- Forcasting the values of all the independent variables of the model over time, by calculating the equations of the time trend of each independent variables, except for the exchange rate will be predicted by the equation of the square with time as the exchange rate increased after the floating currency to reach 18 pounds and then began to decline to the current to about 17 pounds, and then using these equations in the prediction values of these independent variables for future periods of time.

2- Put independent future variable values which obtained from the previous step in reduced form of simutianeous equation model to obtain the expected future values for variables associated with the econometric model ${ }^{7}$.

\footnotetext{
${ }^{7}$ Mohamed, M. 1995. Structural Problems of Development, Publications of the Ministry of Culture, Damascus, Syria.
} 
Table 6. Results of the Theil test $(\mathrm{U})$ for the variables of the simultianeous equation model:

\begin{tabular}{|c|l|c|}
\hline & Internal variables of the the simultianeous equation model & U Thiel \\
\hline 1 & Inflation rate & 0.02 \\
2 & Annual growth rate of GDP in real terms\% & 0.28 \\
\hline
\end{tabular}

Source: Results of the simultianeous equation model.

*Thus, the research can compir between the expected values of both the inflation rate and the rate of growth in GDP until 2025, the results will take three different prediction methods:

1- Forecasting the rate of inflation in Egypt until 2025: From the following table, it was expected that the inflation rates in Egypt using the time trend equation amounted to about 29.19 for 2020, and is increasing to about 31.23 in 2022, then it takes on the rise and even more so up to about 36.79 for the year 2025 , when considering exchange rate effect also in addition to time on the Egyptian inflation rates until 2025, the results are as shown in the following table to show that they are taking a growing trend as well, Whereas comparing these results with their counterparts derived from inflation forecasting in the simutianeous equation model, It is clear that inflation rates are expected in Egypt after taking into the impact of both the independent variables included in the simutianeous equation model on the inflation rate are expected to reach about 22.6 for the year 2020, and is decreasing to reach about 21.1 in 2022, and then take the decreas and even more to reach about 20.7 in 2025.

2- Forecasting the annual growth rate of GDP at real prices in Egypt until 2025: The following table shows that the real GDP growth rate in Egypt is expected to reach the general trend by using the equation to about -0.25 for the year 2020 and continue to decline until about -1.05 for the year 2022 and then arrive To about -2.25 in 2025, when considering exchange rate effect also along with time on the real growth rates of GDP in Egypt until 2025, the results, as shown in the following table, show that they also take a decreasing trend, whereas when compared to those results with its counterpart derived from forecasting real growth rates of GDP from the simutianeous equation model after taking into consideration the effect of both independent variables in the simutianeous equation model on the real growth rate of GDP in Egypt it is expected to reach about 4.56 in 2020 , and is growing even more 5.21 for 2022, and reach about 5.74 for the year 2025 .

\section{Summarize the results}

The first: comparison of the results of the three methods of forecasting for both inflation and growth rates of real GDP in Egypt until 2025: By comparing the forecasting results with both Inflation rates and real GDP growth rates expected in the three methods studied, it is clear that the best forecasts of both rates are the values using simultianeous equation model, As it takes into account all the independent variables affecting the rates of inflation and real growth rates of GDP in Egypt.

Second: Comparison between the results of the forecasting of inflation and growth rates of real GDP in Egypt until 2025: It depending on the results of statistical estimation of external variables affecting growth rates as well as inflation rates, where the situation is very different after the float process, the inflation rate is likely to trend towards an increase in the short term then decrease in the long term. Forecast results indicate that annual growth rates tend to decrease and negative signs in all mathematical equations to forcastimg, except for the results of using simutianeous equation model where it have a positive sign, the effects are logical in terms of expectation according to the economic models that enter all the variables in the statistical estimation. Where forecasts indicate growth rates in 2025 to reach $5.74 \%$ when floating Egyptian pound, which has already occurred and consistent with the policies announced by the Central Bank of Egypt, which is what is relatively consistent with the study expectations. 
Table 7. Forecasting the rate of inflation and the local annual growth rate of GDP at real prices in Egypt until 2025

\begin{tabular}{|c|c|c|c|c|}
\hline \multirow{2}{*}{ Variable } & \multicolumn{4}{|c|}{ Forecastibg } \\
\hline & time trend & & ne trend and Exchange Rate & simutianeous equation model \\
\hline \multicolumn{5}{|c|}{ Forecasting of inflation rate $\left(\mathrm{X}_{2}\right)$} \\
\hline \multicolumn{3}{|c|}{ Average of 2015 for comparison } & 23.00 & \\
\hline 2020 & 29.19 & \multicolumn{2}{|c|}{28.77} & 22.6 \\
\hline 2022 & 31.23 & \multicolumn{2}{|c|}{29.71} & 21.1 \\
\hline 2025 & 36.79 & \multicolumn{2}{|c|}{33.62} & 20.7 \\
\hline \multicolumn{5}{|c|}{ Forecasting of Annual growth rate of GDP at real prices\% $\left(\mathrm{X}_{6}\right)$} \\
\hline \multicolumn{3}{|c|}{ Average of 2015 for comparison } & 3.50 & \\
\hline 2020 & $0.25-$ & \multicolumn{2}{|c|}{$0.92-$} & 4.56 \\
\hline 2022 & $1.05-$ & \multicolumn{2}{|c|}{$1.76-$} & 5.21 \\
\hline 2025 & $2.25-$ & \multicolumn{2}{|c|}{$3.02-$} & 5.74 \\
\hline
\end{tabular}

Source: Data collected from the Economic J., Annual Reports, Monthly Analysis Bulletins, Economic Research Sector, Central Bank of Egypt. And the reduced model derived from the equations of the simultanueous model whose results are reported in Table (5).

\section{REFERENCES}

Abeer A. Qenaoui, 2003. Economics of the Use of Chemical Fertilizers and Pesticides in Egyptian Agriculture, PhD Thesis, Dept. of Agric. Economics, Fac. of Agric., Ain Shams Univ., Cairo, $276 \mathrm{p}$.

Annual Reports, 2003-2015. Monthly analysis bulletins, Economic research sector, Central bank of Egypt, Miscellaneous numbers.

Dominick, S. 1978. Schaum's Outline of Theory and Problems of Statistics and Econometrics, $103 \mathrm{p}$.
Mohamed M. 1995. Structural Problems of Development, Publications of the Ministry of Culture, Damascus, Syria, 53 p.

Rihan, M.K. 1983. Quantitative methods, El- Ain Univ., Abo Dhubai Univ., 186 p.

Rihan, M.K. 2014-2015. Macroeconomics and statistics, Fac. of Agric. Ain Shams Univ., Graduate Studies, Suez Canal Univ., Fac. of Environmental Agric. Sci., Arish, Dept. of Economics and Rural Development, $121 \mathrm{p}$.

Theil, H. 1961. "Economic Forecasts and Policy" $2^{\text {nd }}$ ed., North - Holland, Publishing Company, Amsterdam, 89 p. 